\title{
Transcription Factor SOX-10
}

National Cancer Institute

\section{Source}

National Cancer Institute. Transcription Factor SOX-10. NCI Thesaurus. Code C102893.

Transcription factor SOX-10 (466 aa, $50 \mathrm{kDa}$ ) is encoded by the human SOX10 gene.

This protein is involved in the regulation of gene expression. 